UDC:633.111.1«321+324»:631.527

DOI: 10.15587/2519-8025.2020.206095

\title{
RESISTANCE OF LINES OF WINTER BREAD WHEAT CREATED WITH THE PARTICIPATION OF SPRING-WINTER HYBRIDS TO LEAF STEAD DISEASES
}

\author{
R. Solomonov, A. Kryvenko
}

При вивчені колекиії ярої м'якої пшениці різного генетичного походження, виділені окремі зразки які несуть стійкість до збудників хвороб і можуть бути використанні в якості джерел стійкості до патогенів при гібридизації їх з озимими сортами.

Метою наших досліджень стало отримання стійких до хвороб константних ліній пшениці озимої, із комплексом господарсько-изінних ознак і властивостей.

Матеріали та методи. У наших дослідах основним методом створення нового гібридного матеріалу була внутрішньовидова гібридизація ярої і озимої м'якої пшениці, з наступним добором стійких генотипів різних генерачій на природних (проти борошнистої роси) і штучних (проти бурої та стеблової іржи) інфекційних фонах.

Вихідним матеріалом для досліджень слугували колекція зразків ярої м'якої пшениці різного генетичного і еколого-географічного походження у кількості 101 шт., лінії $F_{3}$ (18 шт.), $F_{4}$ (141 шт.) $i F_{5}$ (66 шт.), створені від комбінацій схрещування ярих зразків з сортами Селекційно-генетичного інституту - Національного центру насіннєзнавства та сортовивчення, різних за біологічними властивостями. Очінку колекційних сортозразків і ліній проводили згідно з загальноприйнятою методикою сортовипробування.

Результати. Наведені результати вивчення стійкості ліній пшениці $F_{3-5}$, створених на базі яро-озимих гібридів, до основних збудників хвороб на природному і штучно створеному інфекційному фоні. Виявлені зв'язки стійкості до збудників хвороб з основними господарсько-иінними ознаками у ліній пшениці. Отримані лінії пшениці з комплексною стійкістю проти збудників листостеблових хвороб.

Висновки. Виділені лінї озимої м'якої пшениці, які поєднують у своєму генотипі відносну стійкість до хвороб з високою продуктивністю. В основному це лініі, створені від схрещування ярих зразків мексиканського, західноєвропейського, канадського та російського походження з місчевими озимими сортами Ключові слова: лінії пиениці, збудники хвороб, стійкість, елементи продуктивності, урожайність

Copyright (C) 2020, R. Solomonov, A. Kryvenko. This is an open access article under the CC BY license (http://creativecommons.org/licenses/by/4.0).

\section{Introduction}

The use of spring wheat in intraspecific hybridization with the winter type has been implemented for many years in various scientific institutions around the world. Thanks to this method, the transfer of the most valuable features and properties from spring to winter wheat has acquired significant opportunities to improve the local variety. First of all, this applies to such important features as the resistance of genotypes to the main pathogens, lodging, germination on the stump; growth of plant productivity due to more intensive accumulation of raw and dry biomass in the spring growing season, grain filling in the extreme period of drought, head size, quantity and weight of grain from head and plant; increase and improvement of baking indicators of grain quality. Therefore, the use of spring samples in the creation of new source material in the selection of winter soft wheat makes a lot of sense.

\section{Literary review}

The production of high-quality grain for food use remains the main task of agricultural producers. The decision of this question without modern means of production is practically impossible. The choice of the variety is sometimes decisive in production among other factors [1].
One of the ways to improve production may be the introduction of new more intensive varieties of wheat, which have advantages over existing ones [2, 3]. First of all, they are highly productive and adapted to the growing conditions in the region, resistant to biotic and abiotic environmental factors. Particular attention is paid to resistance to biotic factors, namely to pathogens of major leaf and stem diseases (powdery mildew, brown leaf and stem rust) [4, 5]. Harmfulness of these diseases is known and the shortage of crops in the years of epiphytotic can reach more than $40-60 \%$ with a decrease in sowing and technological qualities of grain $[6,7]$. Therefore, the creation of diseaseresistant material becomes possible only with the study of collections on artificial infectious backgrounds and with the involvement of new samples in hybridization as sources of resistance [8].

The use of spring samples in the selection of winter wheat reveals a wide variety of shaping process, in terms of the manifestation of new features and properties or their combination or combination in spring-winter hybrids of different generations [9]. Growing hybrid populations at different times allows the selection of genotypes with certain adaptive properties, such as different response to vernalization and photoperiodic sensitivity [10]. Also, the creation of various infectious and provoc- 
ative backgrounds contributes to the selection of more resistant to the main pathogens of wheat genotypes from spring-winter hybrids [11]. The efficiency of using different crossing schemes (simple, saturating backcrosses), allows the transfer of useful features and properties of both spring and winter components of crossing [12, 13].

\section{The purpose and objectives of the study}

The aim of our research was to obtain diseaseresistant constant lines of winter wheat, with a set of economically valuable traits and properties.

To achieve this goal, the following tasks were set:

1. Study of the collection and selection of resistant spring samples of soft wheat of different ecological and geographical origin to pathogens of leaf and stem diseases.

2. Carrying out artificial hybridization of selected spring samples as sources of resistance to pathogens, with winter varieties of wheat.

3. Evaluation of hybrid material of different generations for resistance to pathogens using natural and artificially created infectious backgrounds.

4. Isolation of constant lines of winter soft wheat from populations of spring-winter hybrids, according to a set of economically valuable traits and properties.

\section{Methods and materials}

The main method of creating a new hybrid material is intraspecific hybridization of spring and winter soft wheat, followed by selection of stable genotypes of different generations on artificial infectious backgrounds [10]. The source material for the research was a collection of samples of spring soft wheat of various genetic and ecological-geographical origin in the amount of 101 pieces (Ukraine, Russia, Mexico, Canada, Germany), lines $F_{3}\left(18\right.$ pcs.), $F_{4}\left(141\right.$ pcs.) and $F_{5}(66$ pcs.), created from combinations of crossing spring samples with breeding varieties of the Plant Breeding and Genetics Institute - National Centre of Seed and Cultivar, different in biological properties (Odes'ka 16, Odes'ka 267, Victoria odes'ka, Kuyal'nik, Kiria). Evaluation of collection varieties and lines was performed in accordance with the generally accepted method of variety testing in breeding scientific institutions [14].

Field experiments were established in the fields of the Plant Breeding and Genetics Institute - National Centre of Seed and Cultivar (Odessa). Predecessor - black steam. Plot size: $\mathrm{F}_{3}$ - rows of 1.5 running meters, $\mathrm{F}_{4}-5 \mathrm{~m}^{2}, \mathrm{~F}_{5}-$
$10 \mathrm{~m}^{2}$ in 3 repetitions. Sowing seedier SSFK-7, sowing in rows was done manually, plots - using a combine harvester "Sampo-130". The SDS30'k sedimentation method is an express method for indirect quality of wheat flour in the early stages of selection. It was improved by the staff of the Department of Genetic Fundamentals of Plant Breeding and Genetics Institute. Also, all sedimentation analyses were performed in this department [15].

Spring samples covered a wide variety of five genetic pools. We have previously selected varieties with certain traits and properties that are inherent in this genetic pool. The sample of the Ukrainian pool is represented by the variety of Kharkiv selection (Kharkivs'ka 26). The Russian pool includes two varieties of Ural selection (Altaispace and Volgoural'ska). The North American pool is represented by two Canadian varieties (Glen lea and AC Superb). The Western European pool includes a representative of the German selection - the variety Triso. Varieties of the Central American pool are represented by Mexican varieties (Trap and Babax), which have genes for resistance to brown and stem rust.

Subsequently, the selected samples of spring wheat of each genetic pool were crossed according to the topcross scheme with local varieties-analyzers of different types: Odes'ka 16 - tall extensive type; Odes'ka 267 - tall, semi-intensive type; Victoria unit and Kuyal'nik - medium-sized high-intensity type; Kyria is a semi-dwarf, high-intensity type.

Examinations for diseases were performed during the growing season from the tillering phase (powdery mildew) to wax ripeness (stem rust), according to the generally accepted method [16].

\section{Research results}

As a result of studying the collection samples of spring soft wheat for resistance to the main pathogens of leaf and stem diseases, it was found that resistance is inherent in different samples of origin and to different pathogens. For example, some Russian and Western European specimens of spring wheat were resistant to powdery mildew. Brown rust-resistant specimens were found in all pools of origin, but with the highest resistance score in the Mexican pool.

Absolute resistance to stem rust pathogens was observed in samples of Canadian and Mexican origin. In representatives of other pools, stem rust lesions ranged from 0 to $90 \%$ (Table 1 ).

Table 1

Affection by the main pathogens of the collection of spring samples of different pools of origin of 2006-2008 years, (\%)

\begin{tabular}{|l|c|c|c|c|c|c|c|}
\hline \multirow{2}{*}{ Pools of origin } & \multirow{N}{*}{$\mathrm{N}$} & \multicolumn{2}{c|}{ Powdery mildew } & \multicolumn{2}{c|}{ Brown leaf rust } & \multicolumn{2}{c|}{ Stem rust } \\
\cline { 3 - 8 } & & average & min-max & average & min-max & average & min-max \\
\hline Ukrainian & 16 & $26 \pm 3.8$ & $10-80$ & $31 \pm 3.7$ & $5-80$ & $24 \pm 5.6$ & $0-70$ \\
\hline Russian & 18 & $32 \pm 4.2$ & $0-80$ & $40 \pm 6.4$ & $0-90$ & $25 \pm 4.8$ & $0-70$ \\
\hline Canadian & 8 & $17 \pm 2.6$ & $10-30$ & $14 \pm 4.8$ & $0-50$ & 0 & 0 \\
\hline Western European & 14 & $24 \pm 4.1$ & $0-50$ & $30 \pm 6.2$ & $0-80$ & $36 \pm 3.2$ & $0-90$ \\
\hline Mexican & 28 & $31 \pm 1.9$ & $20-40$ & $4 \pm 0.6$ & $0-10$ & $1 \pm 0.3$ & $0-5$ \\
\hline
\end{tabular}


Evaluation of $\mathrm{F}_{3}$ lines for resistance to brown leaf rust was performed on a natural infectious background. From 18 combinations of crosses, the degree of damage and the number of lines affected as a percentage of the total number of lines were calculated.

Based on the results of the evaluation, it can be concluded that brown rust damage occurs less frequently in lines from combinations with Mexican varieties that carry genes for resistance to brown and stem rust pathogens. This allows the use of varieties of spring wheat of Mexican origin as sources of resistance. At the same time, it follows from the data in Table 2 that the degree of inheritance of disease resistance depends on the level of manifestation of this trait, both in the spring and winter component of crossing.

For example, the number of lines with a degree of damage less than $10 \%$ in combinations with the spring variety Triso and winter variety Odes'ka 267 is $14.6 \%$, and in combination with the winter variety Victoria $66 \%$, with a probability of $95 \%$. Also in different spring varieties in combination with the same winter component of crossing the percentage of lines with different degrees of damage also differs. A striking manifestation is that the winter component of crossing also affects the resistance of the hybrid material to the pathogen of brown rust. Thus, in combination with the variety of Western European origin Triso / Kuyal'nik, the share of lines with a degree of damage of 10-25\% was $57.1 \%$, and with the Mexican variety Trap / Kuyal'nik - $16.7 \%$; in contrast to the line with a degree of defeat of $0 \%$ in the combination Triso / Kuyal'nik was not presence, and Trap / Kuyal'nik - $63.3 \%$.

The study of $\mathrm{F}_{4}$ wheat lines on a set of economically valuable features: yield, sedimentation rate $\mathrm{SDS}_{30}$ ' $\mathrm{k}$, resistance to infectious background to brown and stem rust allowed to evaluate and identify more valuable material (Table 3).

According to the data presented in table 3, you can find the number of lines for each of the 18 combina-

tions of crosses, which exceed or are on a par with the parent form in terms of certain characteristics. Thus, the lines were created with the Western European variety Triso, in terms of yield almost all exceeded the parent varieties, and only in the combination Triso / Kuyal'nik half of the lines had low yields. But in terms of sedimentation, lines from this combination showed a higher average level of $84.8 \mathrm{ml}$ against $73 \mathrm{ml}$ and the number of lines 4 of 6 pcs. exceeded the parent varieties. Resistance to infectious background, these lines showed to brown rust 3-4 points and to stem rust $4-5$ points. Analysing the data in all combinations, we can conclude that most lines exceed the yield of both parent varieties. In terms of sedimentation, on the other hand, most lines have a lower level than the better parent variety, which confirms the opposite relationship between yield and grain quality. Exceptions are lines from the following combinations: Triso / Kuyal'nik ( $84.8 \mathrm{ml})-4$ out of 6 pieces, Volgoural'ska / Odes'ka $267(91.3 \mathrm{ml})-3$ out of 4 pieces, Volgoural'ska / Kuyal'nik $(82.7 \mathrm{ml})-6$ of 11 pcs. The yield of resistant lines (6-8 points) to the pathogens of brown and stem rust from combinations of Mexican varieties was $68-71 \%$.

Thus, it should be noted that the degree of brown rust damage in breeding lines of spring-winter hybrids depends on the level of disease resistance in both spring and winter component of crossing.

It has been shown that breeding lines obtained with the participation of Mexican spring varieties, which are carriers of genes for resistance to brown and stem rust, are found with lower frequency and low level of damage, which allows to recommend spring varieties of Mexican origin for use in breeding programs to create resistant varieties to brown rust together with high productivity.

When evaluating the lines of later generations $\left(\mathrm{F}_{5}\right)$, where selection for resistance to pathogens of leaf, stem rust and powdery mildew was found, different nature of resistance was found both within one combination and between different combinations of crossing (Table 4).

Table 2

The degree and frequency of damage to wheat lines $\mathrm{F}_{3}$ by brown rust in 2009

\begin{tabular}{|l|l|c|c|c|c|c|c|}
\hline \multirow{2}{*}{ No. } & \multicolumn{2}{|}{ Hybrid combination: } & \multirow{2}{*}{$\mathrm{N}$} & \multicolumn{5}{|c|}{ Degree of defeat, \% } \\
\cline { 4 - 7 } & & & $>50$ & $26-50$ & $10-25$ & $<10$ & 0 \\
\hline 1 & Kharkivs'ka 26 / Kyria & 55 & $7.7 \pm 0.2$ & $32.2 \pm 6.3$ & $46.2 \pm 3.6$ & $13.8 \pm 2.3$ & 0 \\
\hline 2 & Triso / Odes'ka 267 & 37 & $7.3 \pm 1.1$ & $46.3 \pm 4.8$ & $31.7 \pm 5.2$ & $14.6 \pm 2.1$ & 0 \\
\hline 3 & Triso / Victoria & 51 & $2.0 \pm 0.4$ & $12.0 \pm 2.3$ & $20.0 \pm 3.4$ & $66.0 \pm 4.9$ & 0 \\
\hline 4 & Triso / Kuyal'nik & 49 & 0 & $10.2 \pm 1.5$ & $57.1 \pm 6.2$ & $28.6 \pm 3.2$ & 0 \\
\hline 5 & Triso / Kyria & 48 & $3.1 \pm 1.4$ & $16.9 \pm 3.8$ & $53.8 \pm 5.7$ & $23.0 \pm 2.2$ & 0 \\
\hline 6 & Altayspace / Odes'ka 267 & 59 & $17.6 \pm 1.8$ & $52.8 \pm 4.7$ & $32.6 \pm 3.5$ & $2.9 \pm 0.3$ & 0 \\
\hline 7 & Altayspace / Kyria & 43 & $29.2 \pm 3.3$ & $41.7 \pm 2.8$ & $29.2 \pm 3.1$ & 0 & 0 \\
\hline 8 & Volgoural'ska / Odes'ka 267 & 37 & $21.5 \pm 1.4$ & $54.2 \pm 4.2$ & $12.5 \pm 2.2$ & $20.8 \pm 1.7$ & 0 \\
\hline 9 & Volgoural'ska / Victoria & 36 & 0 & $13.3 \pm 0.6$ & $16.7 \pm 1.5$ & $70.0 \pm 6.3$ & 0 \\
\hline 10 & Volgoural'ska / Kuyal'nik & 29 & $20.0 \pm 3.2$ & $37.1 \pm 3.4$ & $20.0 \pm 2.6$ & $22.8 \pm 2.8$ & 0 \\
\hline 11 & Glen lea / Odes'ka 267 & 42 & $5.7 \pm 0.2$ & $25.7 \pm 2.5$ & $14.3 \pm 1.8$ & $54.3 \pm 4.3$ & 0 \\
\hline 12 & Trap1 / Odes'ka 267 & 59 & $5.0 \pm 0.3$ & $20.0 \pm 1.6$ & $20.0 \pm 1.3$ & $55.0 \pm 3.6$ & 0 \\
\hline 13 & Trap1 / Victoria & 48 & 0 & 0 & $31.1 \pm 2.9$ & $24.4 \pm 2.1$ & $44.4 \pm 5.2$ \\
\hline 14 & Trap1 / Kuyal'nik & 35 & 0 & $10.0 \pm 1.2$ & $16.7 \pm 0.8$ & $10.0 \pm 0.9$ & $63.3 \pm 4.3$ \\
\hline 15 & Trap1 / Kyria & 62 & 0 & $5.0 \pm 0.4$ & $5.0 \pm 0.3$ & $15.0 \pm 1.6$ & $75.0 \pm 5.8$ \\
\hline 16 & Babax / Odes'ka 16 & 27 & 0 & $5.3 \pm 0.4$ & $5.3 \pm 0.2$ & $5.3 \pm 0.4$ & $84.2 \pm 6.5$ \\
\hline 17 & Babax / Odes'ka 267 & 38 & $3.8 \pm 0.2$ & $19.2 \pm 2.3$ & $19.2 \pm 2.1$ & 0 & $57.7 \pm 4.6$ \\
\hline 18 & Babax / Victoria & 53 & $12.5 \pm 1.3$ & $6.2 \pm 0.5$ & $18.7 \pm 2.2$ & $12.5 \pm 1.6$ & $56.2 \pm 5.1$ \\
\hline
\end{tabular}


Table 3

Important economically valuable indicators of winter wheat lines $\mathrm{F}_{4}$ (2010 year)

\begin{tabular}{|c|c|c|c|c|c|c|c|c|c|c|}
\hline No. & hybrid combination & $\mathrm{N}^{*}$ & Yield c/ha & $\begin{array}{c}\mathrm{N}> \\
\text { p.f } \\
\% \\
* *\end{array}$ & $\begin{array}{c}\text { Indicator } \\
\mathrm{SDS}_{30}{ }^{\circ} \mathrm{k} \\
\mathrm{ml}\end{array}$ & $\begin{array}{c}\mathrm{N}>\mathrm{p} . \\
\mathrm{f} \%\end{array}$ & $\begin{array}{l}\text { Resistance } \\
\text { to brown } \\
\text { rust, } \\
\text { points }\end{array}$ & $\begin{array}{c}\mathrm{N}>\mathrm{p} . \\
\mathrm{f} \%\end{array}$ & $\begin{array}{l}\text { Resistance } \\
\text { to stem } \\
\text { rust, } \\
\text { points }\end{array}$ & $\begin{array}{c}\mathrm{N}>\mathrm{p} . \\
\mathrm{f} \%\end{array}$ \\
\hline 1 & Kharkivs'ka 26 / Kyria & 4 & $51.8 \pm 3.14$ & 100 & $74.0 \pm 3.12$ & 0 & $3.0 \pm 0.82$ & 75 & $4.0 \pm 0.66$ & 75 \\
\hline 2 & Triso / Odes'ka 267 & 6 & $45.9 \pm 2.08$ & 100 & $70.0 \pm 3.53$ & 17 & $3.0 \pm 0.63$ & 17 & $4.0 \pm 0.63$ & 83 \\
\hline 3 & Triso / Victoria & 13 & $46.4 \pm 1.53$ & 92 & $73 \pm 3.05$ & 23 & $3.8 \pm 0.37$ & 85 & $4.4 \pm 0.77$ & 92 \\
\hline 4 & Triso / Kuyal'nik & 6 & $46.0 \pm 2.2$ & 50 & $84.8 \pm 3.05$ & 67 & $3.7 \pm 0.82$ & 50 & $4.7 \pm 1.5$ & 83 \\
\hline 5 & Triso / Kyria & 6 & $53.4 \pm 2.82$ & 100 & $77.0 \pm 5.19$ & 33 & $3.5 \pm 0.55$ & 50 & $5.2 \pm 1.47$ & 100 \\
\hline 6 & Altayspace / Odes'ka 267 & 8 & $46.8 \pm 2.79$ & 87 & $78.6 \pm 4.89$ & 37 & $2.8 \pm 1.09$ & 25 & $6.0 \pm 1.83$ & 37 \\
\hline 7 & Altayspace / Kyria & 4 & $42.4 \pm 2.8$ & 50 & $88.3 \pm 2.33$ & 25 & $3.5 \pm 1.0$ & 75 & $5.0 \pm 1.0$ & 50 \\
\hline 8 & Volgoural'ska / Odes'ka 267 & 4 & $38.7 \pm 1.84$ & 75 & $91.3 \pm 0.88$ & 75 & $3.0 \pm 1.0$ & 0 & $9.0 \pm 2.14$ & 75 \\
\hline 9 & Volgoural'ska / Victoria & 9 & $44.1 \pm 2.25$ & 78 & $78.4 \pm 4.6$ & 33 & $4.9 \pm 2.2$ & 0 & $8.2 \pm 0.67$ & 33 \\
\hline 10 & Volgoural'ska / Kuya'lnik & 11 & $48.2 \pm 2.19$ & 73 & $82.7 \pm 3.8$ & 54 & $4.6 \pm 2.94$ & 27 & $7.1 \pm 2.2$ & 36 \\
\hline 11 & Glen lea / Odes'ka 267 & 4 & $37.4 \pm 5.36$ & 100 & $68 \pm 12.53$ & 25 & $4.3 \pm 0.58$ & 25 & $9.0 \pm 0.05$ & 75 \\
\hline 12 & Trap1 / Odes'ka 267 & 7 & $37.3 \pm 4.3$ & 86 & $53.8 \pm 4.87$ & 14 & $4.0 \pm 2.38$ & 14 & $7.4 \pm 1.81$ & 29 \\
\hline 13 & Trap1 / Victoria & 12 & $36.0 \pm 2.01$ & 83 & $48.2 \pm 2.1$ & 0 & $6.7 \pm 2.23$ & 58 & $7.3 \pm 1.37$ & 17 \\
\hline 14 & Trap1 / Kuyal'nik & 9 & $39.6 \pm 4.84$ & 67 & $68.5 \pm 4.5$ & 44 & $7.0 \pm 2.7$ & 67 & $8.1 \pm 1.05$ & 44 \\
\hline 15 & Trap1 / Kyria & 7 & $51.3 \pm 3.6$ & 100 & $66.0 \pm 0.13$ & 14 & $6.0 \pm 1.83$ & 57 & $8.7 \pm 0.49$ & 71 \\
\hline 16 & Babax / Odes'ka 16 & 5 & $49.1 \pm 5.6$ & 100 & $54.2 \pm 2.2$ & 0 & $6.8 \pm 3.03$ & 60 & $7.6 \pm 1.67$ & 40 \\
\hline 17 & Babax / Odes’ka 267 & 6 & $45.2 \pm 4.7$ & 83 & $61.5 \pm 2.72$ & 50 & $7.2 \pm 2.99$ & 67 & $7.2 \pm 2.48$ & 50 \\
\hline 18 & Babax / Victoria & 11 & $40.7 \pm 1.38$ & 100 & $53.6 \pm 1.66$ & 9 & $6.1 \pm 2.51$ & 36 & $7.5 \pm 1.92$ & 54 \\
\hline
\end{tabular}

Note: ${ }^{*} N$-the number of lines in the experiment;

${ }^{* *} N>p . f . \%$ - the percentage of lines from the combination that exceed the parent forms

Table 4

Resistance of $\mathrm{F}_{5}$ lines of winter soft wheat of different combinations of crossing to pathogens, 2011 year

\begin{tabular}{|c|c|c|c|c|c|c|c|c|}
\hline \multirow[b]{2}{*}{ No. } & \multirow[b]{2}{*}{ Hybrid combination: } & \multirow[b]{2}{*}{$\begin{array}{l}\mathrm{N} \text { of } \\
\text { lines }\end{array}$} & \multicolumn{6}{|c|}{ Resistance in points } \\
\hline & & & $\begin{array}{l}\text { Brown } \\
\text { rustav. }\end{array}$ & $\mathrm{CV}, \%$ & $\begin{array}{c}\text { Stem } \\
\text { rust av. }\end{array}$ & $\mathrm{CV}, \%$ & $\begin{array}{c}\text { Powdery } \\
\text { mildew } \\
\text { av. }\end{array}$ & $\mathrm{CV}, \%$ \\
\hline 1 & Kharkivs'ka 26 / Kyria & 4 & 3.0 & 23.6 & 4.0 & 0 & 3.2 & 25.5 \\
\hline 2 & Triso / Odes'ka 267 & 4 & 3.2 & 13.3 & 4.0 & 0 & 4.0 & 17.7 \\
\hline 3 & Triso / Victoria & 4 & 4.0 & 0 & 5.0 & 14.1 & 4.7 & 9.1 \\
\hline 4 & Triso / Kuyal'nik & 4 & 3.7 & 22.1 & 4.5 & 33.3 & 4.5 & 11.1 \\
\hline 5 & Triso / Kyria & 4 & 3.2 & 13.3 & 4.5 & 11.1 & 4.6 & 10.1 \\
\hline 6 & Altayspace / Odes'ka 267 & 4 & 6.0 & 11.8 & 4.0 & 9.2 & 4.5 & 11.1 \\
\hline 7 & Altayspace / Kyria & 3 & 4.0 & 0 & 4.5 & 11.1 & 7.7 & 10.1 \\
\hline 8 & Volgoural'ska / Odes'ka 267 & 4 & 3.0 & 27.2 & 9.0 & 0 & 3.7 & 22.1 \\
\hline 9 & Volgoural'ska / Victoria & 4 & 3.3 & 14.1 & 8.7 & 5.4 & 5.0 & 0 \\
\hline 10 & Volgoural'ska / Kuyal'nik & 4 & 2.5 & 34.6 & 5.7 & 41.5 & 4.5 & 11.1 \\
\hline 11 & Glen lea / Odes'ka 267 & 3 & 3.7 & 12.8 & 9.0 & 0 & 5.0 & 0 \\
\hline 12 & Trap1 / Odes'ka 267 & 3 & 5.3 & 49.2 & 7.0 & 30.9 & 4.3 & 10.9 \\
\hline 13 & Trap1 / Victoria & 3 & 5.3 & 35.3 & 7.3 & 23.2 & 5 & 0 \\
\hline 14 & Trap1 / Kuyal'nik & 3 & 7.3 & 32.1 & 8.3 & 5.6 & 4.3 & 10.9 \\
\hline 15 & Trap1 / Kyria & 3 & 7.7 & 12.3 & 9.0 & 0 & 3.7 & 12.8 \\
\hline 16 & Babax / Odes'ka 16 & 4 & 7.5 & 34.6 & 7.5 & 22.1 & 2.7 & 30.1 \\
\hline 17 & Babax / Odes'ka 267 & 3 & 5.3 & 53.8 & 5.7 & 41.6 & 2.0 & 0 \\
\hline 18 & Babax / Victoria & 3 & 6.7 & 30.8 & 7.0 & 20.2 & 3.0 & 27.2 \\
\hline
\end{tabular}

The high coefficient of variation shows different combinations of stability within one hybrid combination from stable and unstable components of crossing. This suggests that selection on this basis should be done in later hybrid generations. 
As a result of the research, the collection of spring soft wheat was studied to assess resistance to leaf pathogens. Pathogen-resistant cultivars of different genetic origin were also isolated for hybridization with winter varieties and obtaining hybrid material with different levels of resistance. Among the samples of Mexican origin, two varieties resistant to the pathogen of brown leaf and stem rust were identified - Trap and Babax. High resistance to brown leaf rust are Canadian variety Glen Lea and Russian variety Volgoural'ska. Resistance to the pathogen of powdery mildew possessed samples of the Russian selection Altai space and the Canadian origin of Glen Lea. Their use in hybridization with winter varieties confirmed the resistance of the obtained hybrid material to pathogens in subsequent generations. The artificially created infectious background helped to select among different hybrid populations more resistant lines of wheat to pathogens of the main diseases combining with other valuable signs and properties. The resulting material was resistant to one or more pathogens - group resistance. One major drawback in working with springwinter hybrids in creating the source material of winter wheat is winter hardiness. Although in the process of selection for a set of features and properties, we get a more winter-hardy material at the level of medium-winter-hardy winter varieties, or parent forms.

In this article, we have focused only on hybrids obtained from direct crossing schemes, but we know that to enhance the trait or property, you can use saturating crossing (backcrosses). If we consider in general the selection process of creating a source material that would have a set of positive features and properties for adaptation to growing conditions, it is easier to work and control them in simple hybrids [17]. Therefore, in this article we did not cover all the schemes of crossings, namely backs on the spring and winter component of crossings. However, it has been shown that at presence of backcross on a certain trait in hybrids is intensified [18].
Study limitations. The research was carried out as part of plans to create a new original source material for the selection of soft winter wheat, the Department of Breeding and Seed Production of Wheat of the Breeding and Genetic Institute. For this purpose, the material of collection samples of spring wheat of different genetic origin in the amount of 101 pieces was used.

Prospects for further research. Recombinant lines of soft winter wheat, selected from a set of economically valuable traits, from crossing spring and winter by type of development, are used in the selection process to create high-yielding varieties resistant to biotic and abiotic environmental factors.

\section{Conclusions}

1. According to the results of the study of the collection of spring samples of soft wheat of different genetic origin to the pathogens of leaf and stem diseases, the most stable ones were identified, which reflect the typical characteristics of this pool. For the Ukrainian pool it is the Kharkivs'ka 26 variety, for the Russian pool - Altaispace and Volgoural'ska, the Canadian pool - Glen lea, the Western European pool - Triso, the Mexican pool - Trap and Babax.

2. Thus, for use in hybridization of spring samples of Mexican, Western European and Canadian origin with winter varieties of Odessa selection, we obtain stable lines of winter wheat to pathogens of brown and stem rust with high yields and grain quality.

Resistance of wheat lines to the pathogen of powdery mildew was obtained with the involvement of hybridization of spring wheat of Russian origin (Altaispace).

\section{Conflicts of interest}

The authors declare that they have no conflicts of interest.

\section{References}

1. Alfimov, V. A., Bespalova, L. A., Puzyrnaia, O. IU. (2001). Ustoichivost sortov ozimoi pshenicy v sviazi s izmeneniiami rasovogo sostava v populiacii buroi rzhavchiny Krasnodarskogo kraia. Pshenica i tritikale. Krasnodar, 306-317.

2. Krivchenko, V. I. (1979). Ispolzovanie genofonda v selekcii selskokhoziaistvennykh kultur na ustoichivost k vrednym organizmam. Problemy zaschity rastenii ot vreditelei, boleznei i sorniakov. Moscow: «Kolos», 114-118.

3. Dmitriev, A. P. (2003). Osobennosti biologii vzaimootnoshenii v sisteme parazit-khoziain kak osnova vybora tipa ustoichivosti zernovykh kultur k rzhavchine. Tipy ustoichivosti rastenii k bolezniam. Saint Petersburg, 33-34.

4. Grigoreva, O. G. (1987). Donory effektivnykh genov ustoichivosti k steblevoi rzhavchine pshenicy. Problemy ispolzovaniia genofonda v selekcii rastenii na immunitet k bolezniam i vrediteliam. Leningrad: VIR, 33-37.

5. German, S. E., Kolmer, J. A. (1992). Effect of gene Lr34 in the enhancement of resistance to leaf rust of wheat. Theoretical and Applied Genetics, 84 (1-2), 97-105. doi: http://doi.org/10.1007/bf00223987

6. Voronkova, A. A., Puchkov, Iu. M. (1977). Selekciia pshenicy na ustoichivost k rzhavchine. Krasnodar: Krasnodarskoe kn. izd-vo, 56.

7. Mikhailova, L. A. (2003). Genetika ustoichivosti pshenicy k buroi rzhavchine. Tipy ustoichivosti rastenii k bolezniam. Saint Petersburg, 45-60.

8. Romanenko, A. A., Bespalova, L. A., Kudriashov, I. N., Ablova, I. B. (2005). Novaia sortovaia politika i sortovaia agrotekhnika ozimoi pshenicy. Krasnodar, 224.

9. Khomenko, S. O., Solona, V. Y., Zvarun, T. V. (2011). Osoblyvosti selektsii pshenytsi yaroi v umovakh lisostepu Ukrainy. Selektsiia i nasinnytstvo, 100, 181-191.

10. Babaianc, O. V., Babaianc, L. T. (2014). Osnovy selekcii i metodologiia ocenok ustoichivosti pshenicy k vozbuditeliam boleznei. Odessa: VMV, 401.

11. Bazalii, V. V., Bazalii, H. H., Larchenko, O. V. (2008). Ekolohichna plastychnist i stabilnist urozhainosti sortiv pshenytsi $\mathrm{z}$ riznym typom rozvytku. Faktory eksperymentalnoi evoliutsii orhanizmiv. Kyiv: Lohos, 5, 17-22. 
12. Ablova, I. G. (2008). Principy i metody sozdaniia sortov pshenicy, ustoichivykh k bolezniam i ikh rol v stanovlenii agrosistem. Krasnodar, 49.

13. Kyrychenko, V. V., Petrenkova, V. P., Cherniaieva, I. M. et. al.; V. V. Kyrychenko, V. V., Petrenkova, V. P. (Eds.) (2012). Osnovy selektsii polovykh kultur na stiikist do shkidlyvykh orhanizmiv. Kharkiv: In-t roslynnytstva im. V. Ya. Yurieva, 320.

14. Tkachyk, S. O. (Ed.) (2014). Metodyka provedennia ekspertyzy sortiv roslyn hrupy zernovykh, krupianykh ta zernobobovykh na prydatnist do poshyrennia v Ukraini (PSP). Kyiv: TOV «Nilan-LTD», 82.

15. Rybalka, O. I. (2008). Porivniannia ekspres-metodu sedymentatsii SDS30 pry vyznachenni yakosti zerna y boroshna pshenytsi. Zerno i khlib, 1.

16. Koishibaev, M., Shamanin, V. P., Morgunov, A. I. (2014). Skrining pshenicy na ustoichivost k osnovnym bolezniam. Ankara: FAO-SEK, 64.

17. Dermenko, O. P., Panchenko, Yu. S., Havryliuk, L. L. (2012). Zakhyst pshenytsi ozymoi vid buroi lystkovoi irzhi. Karantyn i zakhyst roslyn, 11, 4-7.

18. Oelke, L. M., Kolmer, J. A. (2005). Genetics of Leaf Rust Resistance in Spring Wheat Cultivars Alsen and Norm. Phytopathology, 95 (7), 773-778. doi: http://doi.org/10.1094/phyto-95-0773

Received date 12.02.2020

Accepted date 03.03.2020

Published date 30.04.2020

Ruslan Solomonov, PhD, Senior Researcher, Scientific and Technological Department Development and Implementation of Innovative Technologies to Intensify Production, Odessa State Agricultural Experiment Station of National Academy of Agrarian Sciences of Ukraine, Maiatska Doroha str., 24, Khlebodar, Odessa region, Ukraine, 67667

E-mail: rusolomonov@ukr.net

Kryvenko Anna, Doctor of Agricultural Sciences, Associate Professor, Deputy Director of Research, Odessa State Agricultural Experiment Station of National Academy of Agrarian Sciences of Ukraine, Maiatska Doroha str., 24, Khlebodar, Odessa region, Ukraine, 67667

E-mail: kryvenko35@ukr.net 